\title{
Neonatal Skin in Mice and Humans Expresses Increased Levels of Antimicrobial Peptides: Innate Immunity During Development of the Adaptive Response
}

\author{
ROBERT A. DORSCHNER, KENNETH H. LIN, MASAMOTO MURAKAMI, AND \\ RICHARD L. GALLO
}

Division of Dermatology, Department of Medicine and Pediatrics, University of California, San Diego, California, U.S.A.; Veterans Administration San Diego Healthcare System, San Diego, California, U.S.A.

\begin{abstract}
The expression of antimicrobial peptides and proteins is an important innate immune defense mechanism that has recently been shown to be essential for cutaneous defense against invasive bacterial disease. Newborns have an immature cellular immune defense system that leads to increased susceptibility to infections. Here we show that skin from embryonic and newborn mice, as well as human newborn foreskin, express antimicrobial peptides of the cathelicidin and $\beta$-defensin gene families. Immunohistochemistry and in situ hybridization demonstrated abundant cathelicidin protein and mRNA is present in normal skin during the perinatal period. Quantitative real-time PCR showed mouse cathelicidin expression (CRAMP) is 10 - to 100 -fold greater in the perinatal period than adult. Murine $\beta$-defensins- 1 and -4 and human $\beta$-defensin- 2 were also present in newborn skin. Combined, human cathelicidin (LL-37/hCAP/18) and $\beta$-defensin-2 demonstrated synergistic antimicrobial activity and ef-
\end{abstract}

\section{ABSTRACT}

ficiently killed group B Streptococcus, an important neonatal pathogen. Antimicrobial peptides may therefore provide a compensatory innate defense mechanism during development of cellular immune response mechanisms in the newborn period.

(Pediatr Res 53: 566-572, 2003)
HBD-2, human $\beta$-defensin-2
Abbreviations
mBD-1,-4, mouse $\beta$-defensin-1, -4
RT-CR, reverse transcriptase PCR
NBT, nitroblue tetrazolium
THB, Todd Hewitt broth
GBS, group B Streptococcus
MBC, minimal bactericidal concentration
GAS, group A Streptococcus
BPI, bactericidal/permeability-increasing protein

The newborn period is characterized by an immaturity of neutrophil function and production (1). Neutrophils in the perinatal period migrate more slowly (2) and granulopoiesis is decreased (3) compared with adults. As a consequence of this relative immunodeficiency, and defects in other aspects of innate and acquired immunity, the preterm and newborn infant has a higher incidence of bacterial infections and a more frequent occurrence of neutropenia in response to sepsis than older children or adults $(4,5)$. Despite this increased susceptibility to infection, however, the vast majority of healthy newborns mount an effective immune defense response to a hostile and microbe-rich external environment.

Received June 21, 2002; accepted November 12, 2002.

Correspondence: Richard L. Gallo, MD, PhD, Mail Code 111B, 3350 LaJolla Village Drive, San Diego, CA 92161,U.S.A.; e-mail: rgallo@UCSD.edu

Supported by a Veterans Administration Merit Review Award, a grant from the National Rosacea Society, and National Institutes of Health grants AI48176 and AR45676 to R.G.

DOI: 10.1203/01.PDR.0000057205.64451.B7
Recent advances in understanding the innate immune system in mammals has provided new insights into alternative antimicrobial defense strategies that were previously underappreciated. Several gene-encoded natural antibiotics are now known, and include families of cationic peptides with potent broad-spectrum activity against bacteria, fungi, and viruses $(6,7)$. In particular, the skin represents a frequently challenged interface with the external environment that can respond to injury or microbial challenge by production of antimicrobial peptides and proteins $(8,9)$.

In adult human skin, expression of antimicrobial peptides belonging to the cathelicidin gene family (LL-37) and the $\beta$-defensin family (HBD-2) is low under normal conditions. After injury or infection, these peptides increase rapidly as a consequence of direct synthesis by the epidermal keratinocytes and deposition from recruited granulocytes (10). Depending on the assay conditions used, these peptides have distinct abilities to inhibit growth or directly kill many Gram-negative and Gram-positive bacteria as well as some fungi. Furthermore, antimicrobial peptides have additional functions, such as inter- 
acting with the adaptive immune system through various mechanisms including leukocyte chemotaxis (11). In mice, a deficiency in cathelicidin production leads to increased susceptibility to necrotic skin infections by GAS (12). These observations support the hypothesis that the production of antimicrobial peptides is an essential element in immune defense.

In this investigation, we hypothesized that the relative deficiency in neutrophil function during the newborn and perinatal period may be partially compensated through enhanced expression of antimicrobial peptides. The expression of the murine cathelicidin (CRAMP) and defensins (mBD-1 and mBD-4) were studied in mouse skin by qualitative immunohistochemistry and in situ hybridization and quantitative measurement of mRNA by RT-PCR. Qualitative evaluation of the expression of the human antimicrobial peptides LL-37 and hBD-2 in newborn foreskin was also done for comparison to the mouse homologues. Finally, the effect of these antimicrobial peptides was studied alone, or in combination, on GBS, an important neonatal pathogen. Our findings support a possible role for antimicrobial peptides during development of the adaptive immune defense system.

\section{MATERIALS AND METHODS}

Immunohistochemistry. Balb/c mouse d 17 embryos (E17) dissected from timed pregnant mothers (Jackson Laboratories, Bar Harbor, ME, U.S.A.), 4-d-old pups, or adult skins were embedded in O.C.T. Compound (Tissue-Tek, Torrance, CA, U.S.A.). Fresh frozen sections were cut at $10 \mu \mathrm{M}$, dried and fixed for $20 \mathrm{~min}$ in $4 \%$ paraformaldehyde in PBS $(138 \mathrm{mM}$ $\mathrm{NaCl}, 2.7 \mathrm{mM} \mathrm{KCl}, 4.3 \mathrm{mM} \mathrm{Na} \mathrm{HPO}_{4} 7 \mathrm{H}_{2} \mathrm{O}, 1.5 \mathrm{mM}$ $\mathrm{KH}_{2} \mathrm{PO}_{4}, \mathrm{pH}$ 7.3). Sections were rinsed in PBS, and endogenous peroxidase activity was quenched for $30 \mathrm{~min}$ with $0.3 \%$ $\mathrm{H}_{2} \mathrm{O}_{2}$ in water and stained using a Vectastain $\mathrm{ABC}$ Elite Standard kit (Vector Laboratories, Burlingame, CA, U.S.A.) per the manufacturer's instructions. Briefly, samples were blocked with $2 \%$ goat serum in PBS for 20 min then incubated for 60 min with primary antibody diluted in PBS $/ 3 \%$ BSA and immunostained as previously described (10). Primary antibodies were either rabbit anti-LL-37 immune serum (with preimmune control) at $5 \mu \mathrm{g} / \mathrm{mL}$, affinity-purified rabbit anti-CRAMP $\operatorname{IgG}$ (with rabbit IgG control) at $0.8 \mu \mathrm{g} / \mathrm{mL}$, or affinity-purified rabbit anti-mBD-4 (with rabbit IgG control) at $10 \mu \mathrm{g} / \mathrm{mL}$ (Alpha Diagnostic Intl., San Antonio, TX, U.S.A.). Sections were washed with PBS and goat anti-rabbit biotinylated antibody (Vector Laboratories) was applied in PBS, 1\% goat serum for $30 \mathrm{~min}$. After washing in PBS, ABC reagent was applied in PBS, 1\% Tween-20. DAB substrate (Sigma Chemical, St. Louis, MO, U.S.A.) was applied for 4 min and Gill's hematoxylin (Vector Laboratories) was used to counterstain, per manufacturer's instructions. All mouse and human tissues were obtained with the approval of the Veteran's Administration San Diego Committee on Animal Studies and the University of California-San Diego Institutional Review Board on Human Subjects, respectively.

$\boldsymbol{R T}$-PCR. RNA was extracted from E15, E17, 1-d-old, 4-dold, and adult mouse skins or mouse femur bone marrow using
TRIzol Reagent (Invitrogen, Carlsbad, CA, U.S.A.) per manufacturer's directions. RT-PCR was performed on 100 ng RNA with Retroscript kit (Ambion, Austin, TX, U.S.A.). Briefly, first-strand synthesis combined RNA with $0.4 \mathrm{mM}$ dNTPs and $4 \mu \mathrm{M}$ decamers in $25 \mu \mathrm{L}$ at $80^{\circ} \mathrm{C}$ for $3 \mathrm{~min}$. The reaction was iced and $2 \mu \mathrm{L}$ 10X RT-PCR buffer, $1 \mu \mathrm{L}$ RNase inhibitor, and $1 \mu \mathrm{L}$ mMuLV RT were added and incubated at $42^{\circ} \mathrm{C}$ for $1 \mathrm{~h}$. Nonquantitative PCR was performed as previously described (10) using the following oligonucleotides: CRAMP: F1 (AGGAGATCTTGGGAACCATGCAGTT) and R1 (GCAGATCTACTGCTCCGGCTGAGGTA). mBD-1: F (GGCTGCCACCACTATGAAAACTC) and R (CCATCGCTCGTCCTTTATGTCCA). mBD-4: F(AACATGCATGACCAATGGAG) and R (TCATCTTGCTGGTTCTTCATCT). 18s primers were from Ambion (classic 18s standard).

Real-time quantitative PCR. Real-time quantitative PCR was performed using a GeneAmp 5700 Sequence Detection System from PerkinElmer (Boston, MA, U.S.A.). 18s Classic Primers (Ambion, TX) were used to amplify 18s; CRAMP-F (CTTCAACCAGCAGTCCCTAGACA) and CRAMP-R (TCCAGGTCCAGGAGACGGTA) to amplify CRAMP cDNA; mBD-4 F (CACATTTCTCCTGGTGCTGCT) and mBD-4 R (GATAATTTGGGTAAAGGCTGCAA) were used to amplify $\mathrm{mBD}-4$. One microliter reverse-transcriptase reaction was used in 23.5 $\mu \mathrm{L}$ SYBR Green PCR Master Mix (Applied Biosystems, Warrington, U.K.) and $0.25 \mu \mathrm{L}$ of each $10 \mu \mathrm{M}$ primer. The thermal profile was as follows: $50^{\circ} \mathrm{C}$ for $2 \mathrm{~min}, 95^{\circ} \mathrm{C}$ for $10 \mathrm{~min}, 40 \mathrm{X}\left(94^{\circ} \mathrm{C}\right.$ for $15 \mathrm{~s}, 60^{\circ} \mathrm{C}$ for $\left.1 \mathrm{~min}\right)$. Results were analyzed using the Comparative $\mathrm{Ct}$ Method, where $\mathrm{Ct}$ is the number of cycles required to reach an arbitrary threshold. This method is based on the assumption that both the target (CRAMP or mBD-4) and reference(18s) primers amplify with the same efficiency within a given range of mRNA starting concentrations. To test this assumption, cDNA was made from mouse bone marrow mRNA as described above with 500, 100, $50,10,5,1$, and 0 ng starting mRNA. RT-PCR was performed on triplicate samples and the change in $\mathrm{Ct}(\Delta \mathrm{Ct})$ calculated. For each starting concentration of mRNA, $\Delta \mathrm{C}_{\mathrm{T}}=\mathrm{C}_{\mathrm{T}, \mathrm{R}}-\mathrm{C}_{\mathrm{T}, \mathrm{G}}$, where $\mathrm{R}=$ reference and $\mathrm{G}=\operatorname{target}$. This was plotted against the log of the starting mRNA concentration. The flatter the slope of the resulting plot, the closer the primer pairs correlate. The efficiencies are close enough to not require a correction factor over the specified range if the slope is $\leq 0.1$. The $\Delta \Delta \mathrm{Ct}$

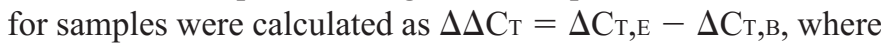
$\mathrm{E}=$ experimental and $\mathrm{B}=$ baseline. The baseline sample is one known to have low expression of the target molecule (adult skin for CRAMP and mBD-4). The experimental samples were the fetal and newborn mouse skins (and adult skin for mBD-4). Relative expression is calculated as $2^{\Delta \Delta \mathrm{CT}}$ to account for the exponential amplification of the PCR reaction.

In situ hybridization. For preparing in situ RNA probes, the PCR product of the CRAMP mature form sequence (CRmf, $159 \mathrm{bp}$ ) was amplified. This product was sequenced to confirm identity, then inserted in the PCR II-TOPO vector (TOPO TA Cloning version $\mathrm{M}$, Invitrogen). Plasmid DNA was subsequently purified using a DNA Extraction Maxi Kit (QIAGEN, Valencia, CA, U.S.A.) and linearized with restriction enzymes (BglII and $\mathrm{XbaI}$ ) for anti-sense and sense RNA probe, respec- 
tively. Digoxigenin-labeled riboprobes were prepared on linearized plasmid using the digoxigenin (DIG) RNA labeling kit (SP6/T7, Roche Molecular Biochemicals, Mannheim, Germany) following the instructions provided. Two microliters of the plasmid containing cDNA for CRmf was blotted on nitrocellulose filters (Osmonics, Westborough, MA, U.S.A.) and UV cross-linked to confirm the specificity of the labeled probes.

Fresh frozen sections, $10 \mu \mathrm{m}$, were fixed with $4 \%$ paraformaldehyde (PFA) for $10 \mathrm{~min}$ at room temperature, and pretreated with $1 \mu \mathrm{g} / \mathrm{mL}$ proteinase $\mathrm{K}$ (Roche Molecular Biochemicals) in PBS for $15 \mathrm{~min}$, at $37^{\circ} \mathrm{C}$. Sections were treated with a $1 \mathrm{M}$ triethanolamine solution $(\mathrm{pH} 8.0)$ containing $0.25 \%$ acetic anhydride for $15 \mathrm{~min}$ at $37^{\circ} \mathrm{C}$, washed with PBS at least three times, then treated with $100 \%$ ethanol for $5 \mathrm{~min}$ and dried. Prehybridization was performed with $50 \%$ formamide in $2 \times$ sodium saline citrate (SSC: $3 \mathrm{M}$ sodium chloride, $0.03 \mathrm{M}$ sodium citrate) for $30 \mathrm{~min}$ at $45^{\circ} \mathrm{C}$. After removing excess solution, sections were hybridized for $16 \mathrm{~h}$ at $45^{\circ} \mathrm{C}$ with sense or antisense DIG-labeled cRNA probes $(1 \mu \mathrm{g} / \mathrm{mL})$ in hybridization solution $[1 \mathrm{mg} / \mathrm{mL}$ yeast tRNA, $20 \mathrm{mM}$ Tris- $\mathrm{HCl}$ buffer (pH 8.0), 2.5 mM EDTA, $1 \times$ Denhart's solution, $0.3 \mathrm{M} \mathrm{NaCl}$, $50 \%$ deionized formamide, $50 \%$ dextran sulfate]. Stringent washing was performed for $60 \mathrm{~min}$ at $45^{\circ} \mathrm{C}$ with $50 \%$ formamide in $2 \times \mathrm{SSC}$, and for $10 \mathrm{~min}$ at $37^{\circ} \mathrm{C}$ with $2 \times \mathrm{SSC}$. RNase treatment was carried out with $40 \mu \mathrm{g} / \mathrm{mL}$ of RNase-A (Roche Molecular Biochemicals) for $30 \mathrm{~min}$ at $37^{\circ} \mathrm{C}$. After washing with the $2 \times \mathrm{SSC}$ for $30 \mathrm{~min}$ at $37^{\circ} \mathrm{C}$, sections were incubated with anti-DIG alkaline phosphate Fab fragment antibody (1:500, in PBS, Roche Molecular Biochemicals) for $5 \mathrm{~h}$ at room temperature. Alkaline phosphate was visualized by incubation with 5-bromo-4-chloro-3-indolyl phosphate (Xphosphate) and NBT with addition of levamisole solution (DAKO, Carpinteria, CA, U.S.A.) overnight at room temperature. Methyl green stain was used for nuclear counter-stain. RNA preservation in tissues was confirmed by similar hybridizations using a keratin 14 antisense probe (insert $175 \mathrm{bp}$ ).

Liquid bacterial killing assay. Bactericidal activity of LL-37 and hBD-2 was tested in a liquid killing assay. GBS COHI type III were grown in THB (Sigma Chemical) to an OD $600 \mathrm{~nm}$ of 0.05 , which corresponds to ca $5 \times 10^{7} \mathrm{CFU} / \mathrm{ml}$. Bacteria were washed two times with $0.1 \%$ THB, $10 \mathrm{mM} \mathrm{Na}$ phosphate, $\mathrm{pH} 7.4$, by centrifuging bacteria $6000 \times g$ for 30 sec, decanting supernatant and resuspended in $0.1 \%$ THB, 10 $\mathrm{mM}$ Na phosphate, $\mathrm{pH}$ 7.4. Bacteria were incubated at $37^{\circ} \mathrm{C}$ for $2 \mathrm{~h}$ with various concentrations of serial diluted synthetic LL-37 and/or hBD-2 from $32 \mu \mathrm{M}$ to $0 \mu \mathrm{M}$. Bacterial cultures were plated in triplicate on THB agar plates and incubated overnight at $37^{\circ} \mathrm{C}$. Colonies were counted and percentage killed was calculated based on number of colonies present in experimental cultures versus a no peptide control culture.

\section{RESULTS}

Expression of cathelicidins is increased in embryonic and newborn skin. In humans and mice, antimicrobial peptides of the cathelicidin family are not detectable in normal adult skin, but are abundantly expressed after injury (7). To determine expression in the perinatal period, immunohistochemical analysis was performed with anti-CRAMP and anti-LL-37 antibodies in mouse and human skin, respectively. CRAMP was detected in E17 through d 4 and primarily located in basal keratinocytes (Fig. 1, $A$ and $E$ ). Expression was highest in $\mathrm{d} 4$ and increased from E15 to d 4 (data not shown). Specificity of the antibody was confirmed on control sections stained with rabbit IgG (Fig. 1, $B$ and $F$ ), and nonspecific association of $\operatorname{IgG}$ was noted in sebaceous structures. Neutrophils were not noted in sections, therefore these cells were not likely to contribute to the protein detected in the epidermis. In situ hybridization confirmed expression in keratinocytes by demonstrating mRNA for CRAMP in E17 skin (Fig. 1C) and d 1 skin (data not shown). Human cathelicidin (LL-37) was also strongly expressed in human newborn foreskin (Fig. 2A), but only barely detectable in healthy adult axilla skin (Fig. $2 B$ ) compared with control sections stained with preimmune sera (insets).

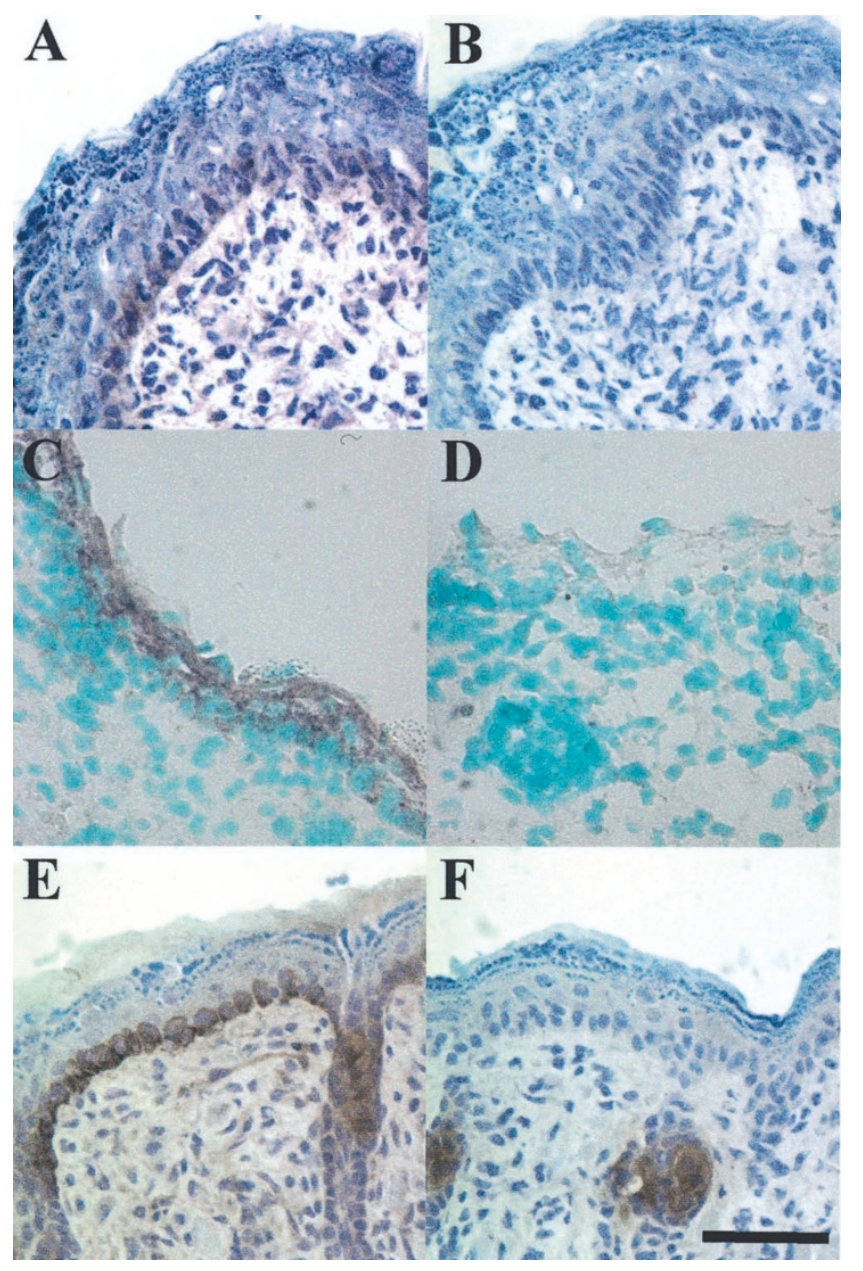

Figure 1. CRAMP protein and message are expressed in newborn mouse skin CRAMP protein expression is detected in mouse embryonic E17 skin $(A)$ and newborn d-4 skin $(E)$ stained with a rabbit anti-CRAMP antibody, but not their isotype-matched control $\operatorname{IgG}$ ( $B$ and $F$, respectively). CRAMP staining was primarily in the basal keratinocytes and around the hair follicle. Staining seen in $F$ represents nonspecific association of IgG with sebaceous gland. In situ hybridizations with DIG-labeled anti-sense probes for CRAMP revealed message expression in the skin of E17 mice $(C)$, whereas the sense probe showed the signal was specific $(D)$. Magnification is at $400 \times$ and the scale bar is 40 $\mu \mathrm{m}$. 


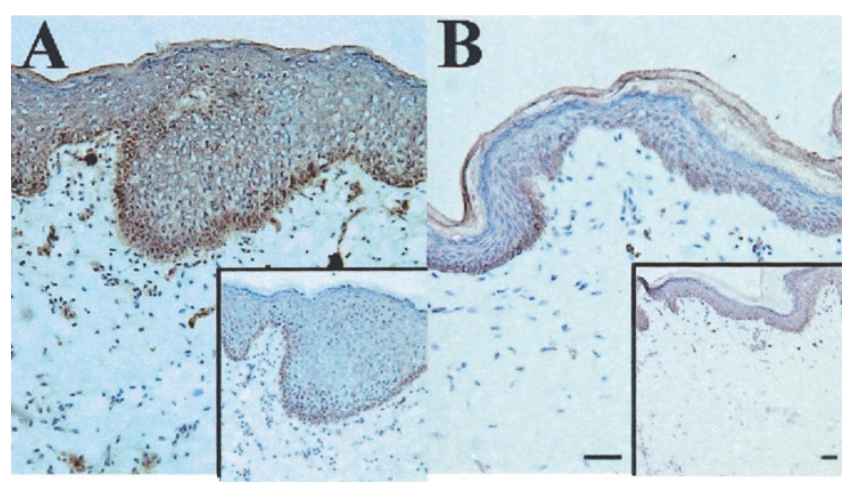

Figure 2. LL-37 is constitutively expressed in newborn foreskin. LL-37 expression in foreskin $(A)$ and adult axillary skin $(B)$ was evaluated with rabbit immune serum and rabbit preimmune serum (insets) as a negative control. Skin from healthy human axilla $(B)$ has almost no LL-37 detectable compared with the preimmune sera control, but newborn human foreskin $(A)$ shows a strong signal throughout the skin, especially in the basal keratinocytes. Magnification is $100 \times$ and the scale bar is $40 \mu \mathrm{m}$.

Quantitative evaluation of CRAMP expression in mouse embryonic and newborn skin. To more quantitatively evaluate the increased expression of cathelicidins seen in perinatal skin in Figure 1, mRNA levels were examined by quantitative real-time RT-PCR in mouse skin at several time points. Assay reliability was evaluated in Figure $3 A$, confirming a linear relationship between sample quantity and cycle number. Mouse E15, E17, d 1, and d 4 skins were compared with adult skin samples and a bone marrow (BM) positive control. Figure $3 B$ shows CRAMP message was increased in both embryonic and newborn skin by between 10- and 100-fold compared with adult skin.

Mouse $\beta$-defensin-4 and $\beta$-defensin-1 mRNA is present in adult, newborn. and embryonic skin. $\beta$-defensins are coexpressed with cathelicidins in the skin during inflammatory conditions and are thought to participate in the antimicrobial peptide defense barrier (13). To evaluate their expression in perinatal skin, RT-PCR was performed on mRNA extracted from embryonic, newborn, and adult mouse (Fig. 4). E17, d 4, and adult skin all had strong mBD-1 signals, as did the esophagus positive control, but not the bone marrow negative control. This contrasted with the data for mBD-4. The esophagus positive control was again highly positive, but the intensity of the faint signal detected in skin for mBD-4 varied across the three ages, with the embryonic having the strongest signal. This data were quantified by real-time PCR in Figure 5, using unique primers for mBD-4 and standardization as done for cathelicidin. In contrast to cathelicidin, mBD-4 mRNA showed higher levels in embryonic and adult skin, but very little in the newborn period.

Human $\beta$-defensin 2 and mouse $\beta$-defensin 4 protein is present in perinatal skin. Immunohistochemistry was performed on human and murine skin to evaluate expression of hBD-2 and mBD-4 protein. The expression pattern of these $\beta$-defensins in neonatal skin was similar in humans and mice. Human neonatal foreskin expressed hBD2 most abundantly in the basal layer, as well as throughout the epidermis (Fig. 6A). In d-4 mouse skin, mBD-4 was expressed evenly throughout the epidermis, without the increased concentration within the
A
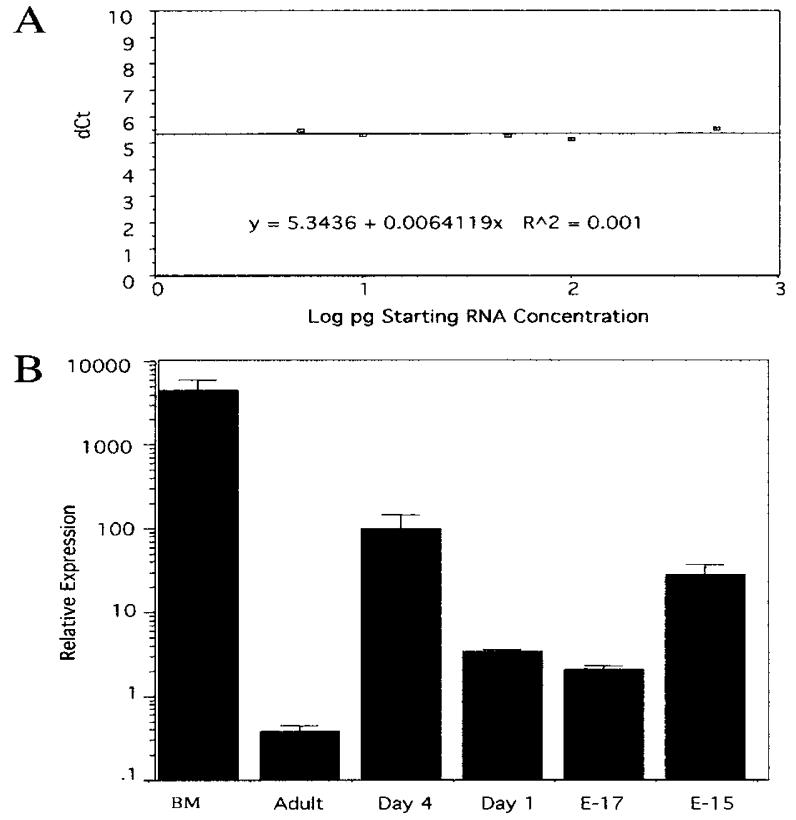

Figure 3. CRAMP mRNA expression is increased in embryonic and newborn mouse skin. RT-PCR was used to determine relative expression levels of CRAMP mRNA in mouse skins of various ages. $(A)$ Cycle thresholds $(C t)$ were used to calculate CRAMP mRNA abundance relative to total RNA. dCT is the difference between $\mathrm{Ct}$ for CRAMP and the $\mathrm{Ct}$ for $18 \mathrm{~S}$ used to normalize for amount of RNA added to each reaction. Because the plot of $\mathrm{dCt} v s$ the log concentration of starting mRNA is $<0.1$, the technique is shown to be accurate for determining amount of CRAMP transcript in this range. $(B)$ The abundance of CRAMP mRNA determined by the $\mathrm{dCt}$ method is increased in the skin of d 1-4 and E15 and E17 mouse pups as compared with adult skin. Bone marrow $(B M)$, the most abundant known source of CRAMP, is shown as relative positive control. These data are representative of three experiments. SE bars are of triplicate samples.

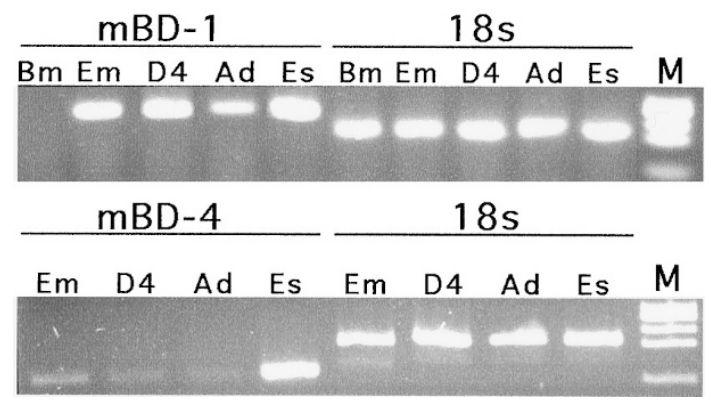

Figure 4. mBD-1 and mBD-4 mRNA are detectable in the skin of embryonic, newborn, and adult mice. mBD-1 was detected in E17 (EM), d 4 (D4), and adult $(A d)$ mouse skins whereas mBD-4 was detected in E17 and weakly in $\mathrm{d}$ 4 and adult skin by RT-PCR. Bone marrow $(\mathrm{Bm})$ negative control was negative and esophagus (Es) positive control is positive for mBD-1 and mBD-4. 18s loading controls show equal amounts of cDNA loaded.

basal keratinocytes seen in human foreskin (Fig. 6C). Consistent with the mRNA expression quantified in Figure 5, adult mouse and human skin also had low but detectable mBD4 and hBD-2 protein by immunostaining (data not shown).

Cathelicidin acts synergistically with hBD-2 to kill GBS. GBS is a potentially lethal infant pathogen. Because both human cathelicidin and $\beta$-defensins were found to be present in perinatal skin, we determined whether they were effective natural antibiotics against this relevant pathogen. Experiments 

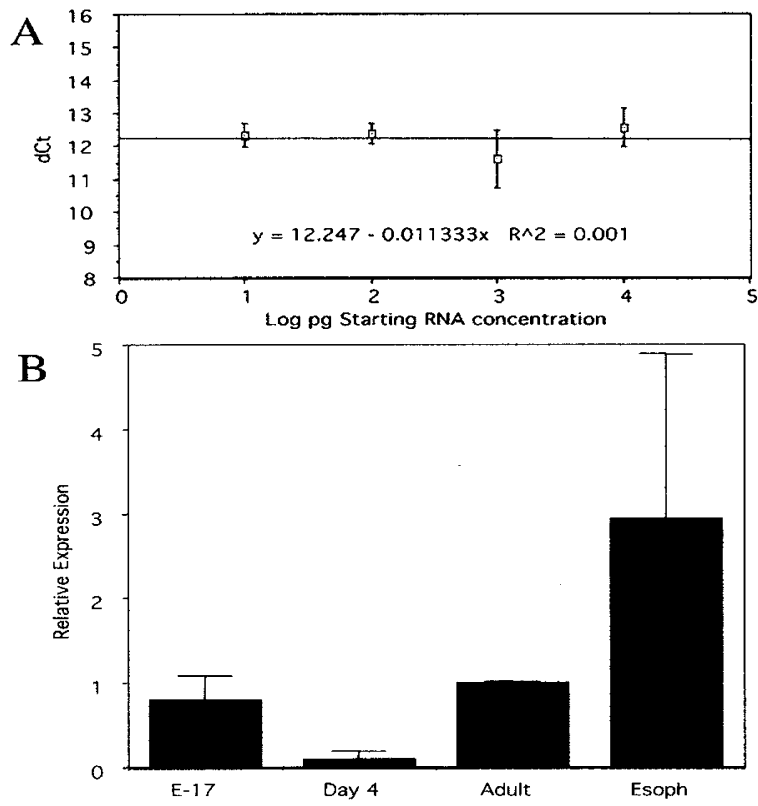

Figure 5. mBD-4 message is expressed in embryonic and adult mouse skin. Real time quantitative PCR was performed on mouse skin to determine the relative expression of mBD-4. $(A)$ Similar to data shown to confirm the accuracy of CRAMP transcript determinations in Figure $3 A$, the plot of $\mathrm{dCt}$ for mBD-4 and $18 \mathrm{~s} v s$ the log of the starting RNA concentration yields a slope of $<0.1$, demonstrating that these primers are also accurate for determining relative mBD-4 expression in this range. $(B)$ The expression of mBD-4 is highest in the skin of E17 and adult mice, while almost undetectable in the skin of $\mathrm{d} 4$ mice. The esophagus positive control has the highest expression, as expected. These data are representative of three experiments. Error bars are of triplicate samples.

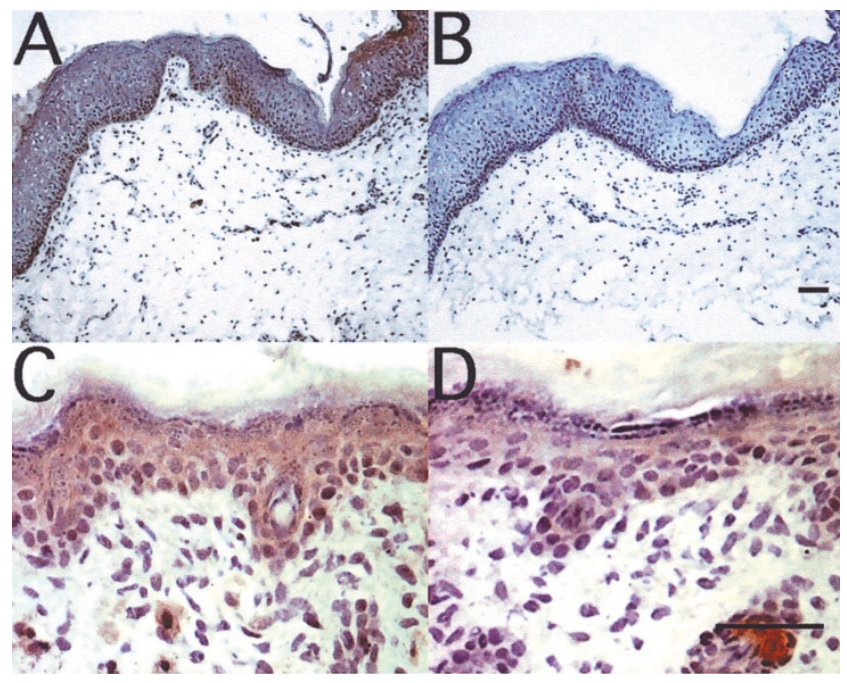

Figure 6. Defensin proteins are expressed in newborn skin. Immunostaining of human newborn foreskin $(A)$ and d-4 mouse skin $(C)$ shows that $\beta$-defensins are expressed in newborn skin. Rabbit antisera was used to detect hBD-2 in skin $(A)$ with preimmune sera as the negative control $(B)$. An affinity-purified rabbit antibody was used to detect mBD-4 in mouse skin $(C)$ and an isotypematched rabbit $\operatorname{IgG}$ is shown as the negative control $(D)$. Scale bars, $40 \mu \mathrm{M}$. Magnification, $100 \times(A$ and $B), 400 \times(C$ and $D)$.

were performed in hypotonic media that can maximize the antimicrobial action of both LL-37 and hBD-2. Figure 7 shows that LL-37 alone had a MBC of $16 \mu \mathrm{M}$ and hBD-2 alone had an $\mathrm{MBC}$ of $8 \mu \mathrm{M}$ against GBS. However, these two peptides

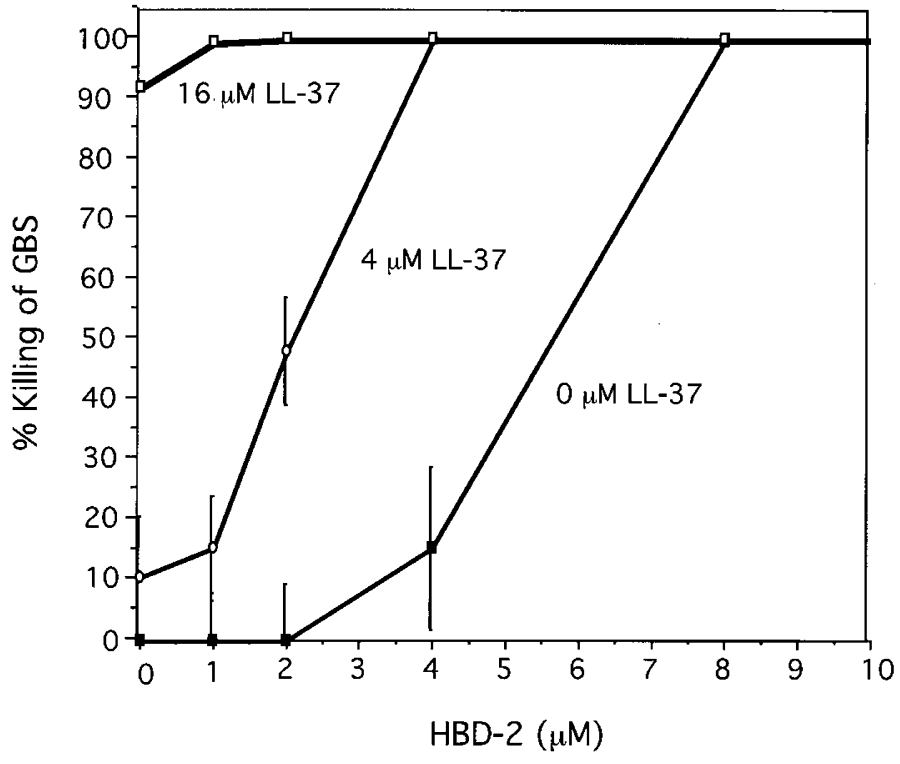

Figure 7. LL-37 and hBD-2 act synergistically to kill GBS. MBC were determined for LL-37 and hBD-2. Bacteria were incubated with serial dilutions of hBD-2 and three concentrations of LL-37; $0 \mu \mathrm{M}$ LL-37 (circles), $4 \mu \mathrm{M}$ LL-37 (triangles), or $16 \mu \mathrm{M}$ LL-37 (squares). Four micromolar $\mu$ of both LL-37 and hBD-2 combined completely killed the GBS, whereas the MBC was $16 \mu \mathrm{M}$ for LL-37 alone and $8 \mu \mathrm{M}$ for hBD-2 alone. Results are representative of three experiments, with the mean and SE of triplicate determinations shown.

combined at $4 \mu \mathrm{M}$ each killed $100 \%$ of GBS, effectively cutting the required $\mathrm{MBC}$ concentration in half or more. Thus, under these conditions the peptides act synergistically to kill GBS.

\section{DISCUSSION}

In the present study, we have shown that skin in the perinatal period constitutively produces antimicrobial peptides. Two antimicrobial gene families were investigated, cathelicidins and $\beta$-defensins. In humans and mouse, a single gene for cathelicidin has been described [reviewed in (14)] and four members of the $\beta$-defensin family are known (15), although more may be present (16). In this study, investigation of the murine cathelicidin (CRAMP) and human cathelicidin (LL37), revealed that in both species, expression is significantly elevated in the perinatal period when compared with adult skin. This relative overexpression of antimicrobial peptide in the newborn was not apparent for murine $\beta$-defensins. These antimicrobials were present in similar amounts when perinatal skin was compared with adult, although mBD-1 mRNA greatly exceeded the expression of mBD-4 and hBD-2. Thus, these observations reveal an enhanced innate immune barrier is present in the skin while some cellular immune defense systems are yet to mature.

The mammalian antimicrobial peptides are expressed in a tissue-specific pattern and in certain circumstances are induced in response to specific stimuli [reviewed in (7)]. For cathelicidin, expression has been described as most abundant in leukocyte precursors within the bone marrow (17), within epithelial tissues such as those of the gastrointestinal tract (18) and lung 
(19), in seminal fluid (20), and after injury within keratinocytes of the skin $(21,10)$. The expression of $\beta$-defensins overlaps in specific situations with cathelicidins, most notably hBD-2 (the homologue of murine mBD-4), and is highly induced in keratinocytes in conjunction with the human cathelicidin LL-37 in inflammatory skin conditions such as psoriasis $(13,21)$. Both cathelicidin and $\beta$-defensin expression is minimal in normal adult skin, suggesting that alternative innate immune defense systems are functioning in noninjured adult skin. However, the present findings contrast to these prior observations in the adult. In skin obtained during the newborn period from both mice and humans, cathelicidin and $\beta$-defensin expression is present in the absence of inflammation. In the case of CRAMP, expression was highly abundant, approaching that seen after injury of adult skin (10). The elevated expression observed in newborn skin was not the result of undetected injury or bacterial stimulation, as high levels of expression were seen when harvested immediately from normal mouse embryos dissected under sterile conditions. Furthermore, although LL-37 expression was only investigated in newborn foreskins, thus presenting the possibility that location rather than developmental age could explain these observations, in the embryonic and newborn mouse increased CRAMP expression in skin was generalized and not dependent on location.

To explore the potential functional significance of increased antimicrobial peptide to the newborn, we have shown that LL-37 and hBD-2 have synergistic antimicrobial activity against the neonatal pathogen GBS. The sensitivity of GBS to either LL-37 or hBD-2 was much less than GAS, the more frequent pathogen in adults (10). This relative resistance of GBS to these antimicrobial peptides may explain, in part, the frequency of GBS as a neonatal pathogen compared with GAS, the more frequent pathogen in adults whose skin have a relative lack of LL-37 and hBD-2 under normal conditions. Studies of the innate antimicrobial activity of LL-37 and hBD-2 alone $(13,22)$, or the enhanced activity of antimicrobial peptides when combined $(23,24)$, provide additional support our observations that these peptides kill important potential pathogens. Furthermore, the presence of natural antibiotics in skin has been shown in vivo to be essential for resistance to GAS; CRAMP-deficient adult mice challenged with GAS developed larger skin infections and take longer to repair necrotic skin lesions than their wild-type littermates (12). This dependence on production of cathelicidin in mouse skin was observed in the adult period, and was seen despite an otherwise apparently normal cellular adaptive immune response system. The present findings also suggest that the regulation of cathelicidin expression differs from that of the $\beta$-defensins. This is consistent with known differences in their tissue-specific expression as well as our observations that IL-4 and IL-13, cytokines that are elevated in atopic dermatitis, can decrease expression of HBD-2 but not LL-37 (25).

Newborns have a diminished ability to initiate an appropriate neutrophil functional response and stimulate proliferation in response to bacterial infection (1). Among the defects in neonatal neutrophil function are a relative deficiency in the antimicrobial protein bactericidal/permeability-increasing protein (BPI), but normal levels of $\alpha$-defensin antimicrobial pep- tides (26). In consideration of this relative deficiency in cellular immune function, it is attractive to speculate that an augmented innate antimicrobial peptide defense mechanism is beneficial to the newborn and provides an essential level of microbial protection. Precedence for the expression of cathelicidins as a potential mechanism for augmenting neonatal immune response has been previously described in the pig, whose ability to produce multiple members of the cathelicidin gene family is augmented in blood neutrophils before $42 \mathrm{~d}$ of age (27). Furthermore, human $\beta$-defensin- 1 expression has been described in breast milk and in breast tissue during lactation (28, 29 ), and expression of defensin peptides has been described in newborn mouse intestine (30) and in necrotizing enterocolitis (31). Prior studies have also shown that in several animal models the constitutive over expression of antimicrobial peptides at epithelial interfaces provides an enhanced level of protection against bacteria (32). Furthermore, cathelicidins and $\beta$-defensins interact with adaptive immune systems through stimulation of chemotaxis $(33,34)$, a function that may be either beneficial to the host if activity is manifested in appropriate response to microbial challenge, or deleterious if this leads to inappropriate skin inflammation. In addition, because these peptides have other activities on the host that do not relate directly to antimicrobial action (35), it is possible that the differences in expression seen in the newborn period relate to these effects and not solely to antimicrobial action. Further analysis of antimicrobial peptide expression and function in the neonatal period will therefore be important to enhance understanding immune defense in the newborn and provide potential therapeutic strategies not previously considered.

Acknowledgments. The authors thank Dr. Birgitta Agerberth for the generous gift of anti-LL-37 antibody and Dr. Tomas Ganz for HBD-2 peptide.

\section{REFERENCES}

1. Carr R 2000 Neutrophil production and function in newborn infants. Br J Haematol $110: 18-28$

2. Raghunathan R, Miller ME, Everett S, Leake RD 1982 Phagocyte chemotaxis in the perinatal period. J Clin Immunol 2:242-245

3. Christensen RD, Harper TE, Rothstein G 1986 Granulocyte-macrophage progenitor cells in term and preterm neonates. J Pediatr 109:1047-1051

4. Gladstone IM, Ehrenkranz RA, Edberg SC, Baltimore RS 1990 A ten-year review of neonatal sepsis and comparison with the previous fifty-year experience. Pediatr Infect Dis J 9:819-825

5. Schelonka RL, Infante AJ 1998 Neonatal immunology. Semin Perinatol 22:2-14

6. Ganz T, Weiss J 1997 Antimicrobial peptides of phagocytes and epithelia. Semin Hematol 34:343-354

7. Zasloff M 2002 Antimicrobial peptides of multicellular organisms. Nature 415:389 395

8. Gallo R, Huttner K 1998 Antimicrobial peptides: an emerging concept in cutaneous biology. J Invest Dermatol 111:739-743

9. Canny G, Levy O, Furuta GT, Narravula-Alipati S, Sisson RB, Serhan CN, Colgan SP 2002 Lipid mediator-induced expression of bactericidal/permeability-increasing protein (BPI) in human mucosal epithelia. Proc Natl Acad Sci U S A 99:3902-3907

10. Dorschner RA, Pestonjamasp VK, Tamakuwala S, Ohtake T, Rudisill J, Nizet V, Agerberth B, Gudmundsson GH, Gallo RL 2001 Cutaneous injury induces the release of cathelicidin anti-microbial peptides active against group A Streptococcus. J Invest Dermatol 117:91-97

11. Yang D, Chertov O, Oppenheim JJ 2001 The role of mammalian antimicrobial peptides and proteins in awakening of innate host defenses and adaptive immunity. Cell Mol Life Sci 58:978-089

12. Nizet V, Ohtake T, Lauth X, Trowbridge J, Rudisill J, Dorschner RA, Pestonjamasp V, Piraino J, Huttner K, Gallo RL 2001 Innate antimicrobial peptide protects the skin from invasive bacterial infection. Nature 414:454-457

13. Harder J, Bartels J, Christophers E, Schroder JM 1997 A peptide antibiotic from human skin. Nature 387:861 
14. Lehrer RI, Ganz T 2002 Cathelicidins: a family of endogenous antimicrobial peptides Curr Opin Hematol 9:18-22

15. Garcia JR, Krause A, Schulz S, Rodriguez-Jimenez FJ, Kluver E, Adermann K, Forssmann U, Frimpong-Boateng A, Bals R, Forssmann WG 2001 Human betadefensin 4: a novel inducible peptide with a specific salt- sensitive spectrum of antimicrobial activity FASEB J 15:1819-1821

16. Schutte BC, Mitros JP, Bartlett JA, Walters JD, Jia HP, Welsh MJ, Casavant TL, McCray PB, 2002 Discovery of five conserved beta -defensin gene clusters using a computational search strategy. Proc Natl Acad Sci U S A 99:2129-2133

17. Storici P, Zanetti M 1993 A novel cDNA sequence encoding a pig leukocyte antimicrobial peptide with a cathelin-like pro-sequence. Biochem Biophys Res Commun 196:1363-1368

18. Hase K, Eckmann L, Leopard JD, Varki N, Kagnoff MF 2002 Cell differentiation is a key determinant of cathelicidin LL-37/human cationic antimicrobial protein 18 expression by human colon epithelium. Infect Immun 70:953-963

19. Bals R, Wang X, Zasloff M, Wilson JM 1998 The peptide antibiotic LL-37/hCAP-18 is expressed in epithelia of the human lung where it has broad antimicrobial activity at the airway surface. Proc Natl Acad U S A 95:9541-9546

20. Malm J, Sorensen O, Persson T, Frohm-Nilsson M, Johansson B, Bjartell A, Lilja H, Stahle-Backdahl M, Borregaard N, Egesten A 2000 The human cationic antimicrobial protein (hCAP-18) is expressed in the epithelium of human epididymis, is present in seminal plasma at high concentrations, and is attached to spermatozoa. Infect Immun 68:4297-4302

21. Frohm M, Agerberth B, Ahangari G, Stahle-Backdahl M, Liden S, Wigzell H, Gudmundsson GH 1997 The expression of the gene coding for the antibacterial peptide LL-37 is induced in human keratinocytes during inflammatory disorders. J Biol Chem 272:15258-15263

22. Turner J, Cho Y, Dinh NN, Waring AJ, Lehrer RI 1998 Activities of LL-37, cathelin-associated antimicrobial peptide of human neutrophils. Antimicrob Agents Chemother 42:2206-2214

23. Nagaoka I, Hirota S, Yomogida S, Ohwada A, Hirata M 2000 Synergistic actions of antibacterial neutrophil defensins and cathelicidins. Inflamm Res 49:73-79

24. Scott MG, Hancock RE 2000 Cationic antimicrobial peptides and their multifunctional role in the immune system. Crit Rev Immunol 20:407-431
25. Ong PY, Ohtake T, Brandt C, Strickland I, Boguniewicz M, Ganz T, Gallo RL, Leung DYM 2002 Endogenous antimicrobial peptides and skin infections in atopic dermatitis. N Engl J Med 347:1151-1160

26. Levy O, Martin S, Eichenwald E, Ganz T, Valore E, Carroll SF, Lee K, Goldmann D, Thorne GM 1999 Impaired innate immunity in the newborn: newborn neutrophils are deficient in bactericidal/permeability-increasing protein. Pediatrics 104:1327-1333

27. Wu H, Zhang G, Ross C, Blecha F 1999 Cathelicidin gene expression in porcine tissues: roles in ontogeny and tissue specificity. Infect Immun 67:439-442

28. Liepke C, Zucht HD, Forssmann WG, Standker L 2001 Purification of novel peptide antibiotics from human milk. J Chromatogr B Biomed Sci Appl 752:369-377

29. Jia HP, Starner T, Ackermann M, Kirby P, Tack BF, McCray PB 2001 Abundant human beta-defensin-1 expression in milk and mammary gland epithelium. J Pediatr 138:109-112

30. Darmoul D, Brown D, Selsted ME, Ouellette AJ 1997 Cryptdin gene expression in developing mouse small intestine. Am J Physiol 272:G197-G206

31. Salzman NH, Polin RA, Harris MC, Ruchelli E, Hebra A, Zirin-Butler S, Jawad A, Martin Porter E, Bevins CL 1998 Enteric defensin expression in necrotizing enterocolitis. Pediatr Res 44:20-26

32. Bals R, Weiner DJ, Moscioni AD, Meegalla RL, Wilson JM 1999 Augmentation of innate host defense by expression of a cathelicidin antimicrobial peptide. Infect Immun 67:6084-6089

33. De Y, Chen Q, Schmidt AP, Anderson GM, Wang JM, Wooters J, Oppenheim JJ, Chertov O 2000 LL-37, the neutrophil granule- and epithelial cell-derived cathelicidin, utilizes formyl peptide receptor-like 1 (FPRL1) as a receptor to chemoattract human peripheral blood neutrophils, monocytes, and T cells. J Exp Med 192:10691074

34. Yang D, Chertov O, Bykovskaia SN, Chen Q, Buffo MJ, Shogan J, Anderson M, Schroder JM, Wang JM, Howard OM, Oppenheim JJ 1999 Beta-defensins: linking innate and adaptive immunity through dendritic and T cell CCR6. Science 286:525528

35. Zaiou M, Gallo RL 2002 Cathelicidins, essential gene-encoded mammalian antibiotics. J Mol Med 80:549-561 